\title{
Performance of broiler chickens fed South African sorghum-based diets with xylanase
}

\author{
M. Mabelebele ${ }^{1 \#}$, R.M. Gous ${ }^{2}$, M. Siwela ${ }^{2}$, H.V.M. O'Neil ${ }^{3}$ and P.A. Iji \\ ${ }^{1}$ University of South Africa, College of Agricultural and Environmental Science, Florida Campus, Rooderpoort, \\ Johannesburg, South Africa \\ ${ }^{2}$ University of Kwa-Zulu Natal, School of Rural, Earth and Environmental Science, Scottsville, Pietermaritzburg, Kwa- \\ Zulu Natal, South Africa \\ ${ }^{3}$ AB Vista Feed Ingredients, Marlborough, Wiltshire, SN8 4AN, United Kingdom \\ ${ }^{4}$ University of New England, School of Environmental and Rural Science, Armidale, NSW 2351, Australia
}

(Received 18 May 2017; Accepted 13 August 2017; First published online 10 September 2017)

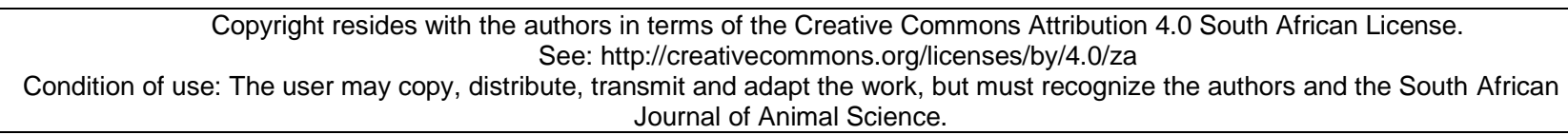
Journal of Animal Science.

\begin{abstract}
Two experiments were conducted to determine the influence of sorghum variety and xylanase on performance of broiler chickens. In Experiment 1A, a total of 240 day-old Ross broiler chickens were assigned to a 2 (sex) $\times 3$ (sorghum variety) $\times 2$ (with or without xylanase) factorial arrangement in a completely randomized design with 20 chickens per treatment. Gross performance measurements were assessed at 7, 14, and 21 days of age. Carcass yield and visceral organ weights were measured at day 21. In Experiment 1B, a total of 108 female Ross 308 broiler chickens were randomly assigned to a 3 (sorghum variety) $\times 2$ (with or without xylanase) factorial arrangement in a completely randomized design with 6 treatments replicated 6 times. On day 25, all birds were euthanazed by intravenous injection of sodium pentobarbitone and digesta contents from the distal ileum were collected to determine the nutrient digestibility. Broiler chickens offered sorghum variety Pan8816 supplemented with xylanase had higher feed intake, weight gain, and similar feed conversion ratio at 1 - 7 days of age. Breast meat of broiler chickens was not affected by variety or xylanase. The small intestine was heavier in the Pan8625 and Pan8816 groups with xylanase than in the similar Pan8906 group. Enzyme inclusion increased the crude protein digestibility. When xylanase was included in all sorghum varieties, numerically, starch digestibility tended to improve. Sorghum variety affected the growth performance of broiler chickens. Furthermore, nutrient digestibility was affected by the differences in variety.
\end{abstract}

Keywords: Digestibility, tannin, poultry, visceral organs, xylanase

\# Corresponding author: mabelebelem@gmail.com

\section{Introduction}

Sorghum-based diets are associated with inferior broiler performance in comparison to maize- and wheat-based diets (Selle et al., 2010). This inferiority has been observed in terms of breast meat yield and feed efficiency, which are crucial in broiler production. The purpose of adding enzymes to poultry feeds is mainly to improve the utilisation of nutrients. As described by Bedford and Schulze (1998), the mechanisms of xylanase include the degradation of the non-starch polysaccharides (NSP) in the cell wall matrix of the ingredients with the release of the encapsulated nutrients and lowered viscosity of digesta caused by soluble NSP and improved rate of diffusion between enzymes and digestion end products. Furthermore, xylanase increases accessibility of nutrients to endogenous digestive enzymes, stimulation of intestinal motility, improved feed passage rate, and supplementation of the enzyme capacity of young chicks. Xylanases, $\beta$ glucanases, and phytases are enzymes commonly used in poultry feeds. Sorghum is an important cereal crop and plays a key role in animal feed (Kaufman et al., 2013). Although sorghum is similar to maize in chemical composition, it has been associated with sub-optimal and inconsistent poultry performance (Black et al., 2005; Bryden et al., 2009). Some sorghum varieties may contain condensed tannin, which has pronounced anti-nutritive properties. Grain sorghum contains high levels of phytate or phytic acid (Dorhorty et al., 1982). In addition to chelating minerals, phytate binds with protein through binary and ternary complexes and binds with starch directly or indirectly through starch granule-associated protein (Baldwin, 
2001; Oatway et al., 2001). Due to this relationship, the enzymatic degradation of phytate increases availability of starch and protein in the sorghum.

The use of phytase in poultry feed has also increased in response to increasing concerns over phosphorus $(P)$ pollution in the environment. The hydrolysis of the phytate increases the availability of phytate-bound $\mathrm{P}$ (phytate-P) and reduces its excretion (Simons et al., 1990). It also increases protein and starch utilisation (Selle et al., 2010). Combinations of xylanase and phytase have been of great interest in wheat-based diets. Xylanase reduces the digesta viscosity and releases the nutrients that are entrapped in the cell wall matrix. Enhanced apparent metabolisable energy (AME) and improved protein digestibility in wheat-based diets supplemented with xylanase and phytase have been reported (Ravindran et al., 1999). Despite the popularity of the use of phytase and carbohydrases or their combinations in wheat- and barleybased diets, published data on their use in sorghum is very limited. Consequently, two sub-experiments were conducted to evaluate the impact of exogenous enzymes added to South African sorghum-based diets on growth performance, internal organs, and nutrient utilisation of broiler chickens.

\section{Materials and methods}

A total of 480 day-old sexed Ross 308 broiler chicks ( $40.10 \mathrm{~g}$ weight), obtained from National Chicks (Pietermaritzburg, Kwa-Zulu Natal, South Africa), and were used in Experiments 1A and 1B. Chicks according to their experiments were assigned to cages $(42 \times 75 \times 25 \mathrm{~cm})$ in four-tier battery brooders housed in an environmentally controlled room. Initial brooding temperature was $33^{\circ} \mathrm{C}$, but was gradually reduced to $24 \pm 1{ }^{\circ} \mathrm{C}$ at 19 days of age. The first day, 24 hours of light was provided, after 18 hours of lighting and 6 hours darkness was maintained each day. Access to feed and water was ad libitum. The Animal Ethics Committee of the University of KwaZulu-Natal, UKZN, Pietermaritzburg, KwaZulu-Natal, South Africa approved the experiment, with approval number 016/14/Animal.

Three commercial hybrid sorghum varieties were selected for their outstanding yield performance, agronomic characteristics, preference by farmers and tannin contents. The sorghum varieties, Pan8816 (non-tannin variety, $0.1 \mathrm{mg}$ of catechin equivalent $/ 100 \mathrm{mg}$ ), Pan8906 (non-tannin variety, $0.2 \mathrm{mg}$ of catechin equivalent $/ 100 \mathrm{mg}$ ) and Pan8625 (tannin variety, $2.0 \mathrm{mg}$ of catechin equivalent/100mg) were grown in a controlled field trial at Pannar Research Services (Pty) Ltd, Klerksdorp, South Africa of November 2013 to February 2014. The mean temperature was $27.3^{\circ} \mathrm{C}$ and rainfall of $527 \mathrm{~mm}$ (South African Weather Services, http:/www.weathers.co.za). The grains were field-dried and harvested at less than $14 \%$ moisture content. The chemical and nutritional properties of the selected varieties were considered and reported by Mabelebele et al. (2015).

The basal starter diet was formulated to meet the requirements as recommended in the Ross broiler specifications (Aviagen, 2014). The diets were supplemented with 500 FTU microbial phytase (Quantum Blue, AB Vista Feed Ingredients Marlborough, UK) and with or without 1600 BXU of xylanase (Econase XT, AB Vista Feed Ingredients Marlborough, UK) for a total of six experimental diets (Table 1). PAN8816 plus phytase with or without $1600 \mathrm{BXU} / \mathrm{kg}$ xylanase, PAN8625 with $500 \mathrm{FTU} / \mathrm{kg}$ phytase with or without 1600 $\mathrm{BXU} / \mathrm{kg}$ xylanase and PAN8906 with $500 \mathrm{FTU} / \mathrm{kg}$ phytase with or without $1600 \mathrm{BXU} / \mathrm{kg}$ xylanase). The diets were fed as mash to male and female broiler chickens from one to 21 days of age. For experiment $1 \mathrm{~A}$ each treatment was randomly assigned to 24 pens in a 2 (sex) $\times 3$ (sorghum variety) $\times 2$ (with or without 1600 $\mathrm{BXU}$ xylanase $/ \mathrm{kg}$ diet) factorial arrangement in a completely randomized design with 10 chickens per pen. Feed intake and body weight measurements were taken weekly and used to calculate growth performance. The mortality was recorded as it occurred. At 21 days of age, two chickens per pen with an average mean pen weight was taken, weighed and slaughtered. The carcass traits and visceral organs were weighed and dressed weight determined. The carcass was subsequently weighed, followed by removal and weighing of breast, thighs and drumsticks, all bone-in with skin.

For experiment $1 \mathrm{~B}$ a total of 108 female broiler chickens were randomly assigned to 18 pens to a 3 (sorghum variety) $\times 2$ (with or without xylanase) factorial arrangement in a completely randomised design with 6 chickens per replicate. The diets were formulated similar to that of experiment $1 \mathrm{~A}$. Celite, a major component of acid-insoluble ash, was included in the diet as an inert marker. Initial and final feed intake and body weight for an experimental period of four days was measured. On day 25 , all birds were euthanazed by intravenous injection of sodium pentobarbitone, digesta contents from the distal half of the ileum were collected and processed as described previously (Ravindran et al., 1999a).

The nitrogen $(\mathrm{N})$ contents of diet and ileal digesta samples were analysed using a FP-428 nitrogen determinator (LECO $\AA$ Corporation, St. Joseph, Michigan, USA) as described by Sweeney (1989). Nitrogen freed by combustion at high temperature in pure oxygen was measured with a thermal conductivity detector using helium as a reference and converted to crude protein using a numerical factor of 5.70. The furnace temperature was maintained at $950{ }^{\circ} \mathrm{C}$ for hydrolysis of samples in ultra-high purity oxygen. To interpret detector response as percentage nitrogen (w/w), calibration was carried out using a pure primary standard of 
ethylenediaminetetraacetic acid (EDTA). Diet and ileal digesta samples were also analysed for phosphorus by the inductively coupled plasma (ICP) method (Vista MPX-radial) as described by Anderson and Henderson (1986). Acid insoluble ash was determined using the method described by Vogtmann et al. (1975). A $5 \mathrm{~g}$ (feed) or $4 \mathrm{~g}$ sample (excreta) was placed in a previously weighed glass beaker to which $50 \mathrm{ml}$ of $4-\mathrm{N} \mathrm{HCl}$ added. The beaker was covered with a watch glass and boiled gently for $45 \mathrm{~min}$. The slurry was then filtered through ashless filter paper and washed twice with double-distilled water. The filter paper containing the washed residue was placed in a dried, pre-weighed crucible and dried for $24 \mathrm{~h}$ at $70^{\circ} \mathrm{C}$. The dried residue was then ashed at $600{ }^{\circ} \mathrm{C}$ for at least $4 \mathrm{~h}$, allowed to cool in a desiccator, and weighed to determine the weight of the cooled ash (acid insoluble ash). The crude protein content was calculated by multiplying it with a factor of 6.25. Starch and fat was measured following the standard method of AOAC (2005). The apparent ileal protein digestibility coefficients were calculated using the below formula:

$$
\text { Apparent nutrient digestibility }(\%)=\frac{(\mathrm{NT} / \mathrm{AIA})_{d}-(\mathrm{NT} / \mathrm{AIA})_{i}}{(\mathrm{NT} / \mathrm{AI} A)_{d}} \times 100
$$

Where: $(\mathrm{NT} / \mathrm{AIA})_{\mathrm{d}}=$ ratio of nutrient and acid insoluble ash in diet, and

$(\mathrm{NT} / \mathrm{AIA})_{i}=$ ratio of nutrient and acid insoluble ash in ileal digesta.

The data were statistically analysed by the general linear model procedure using a SAS version 10 software program (SAS, 2008). Tukey's test was used to compare means where the effect of treatments was significant at the $5 \%$ level of probability.

\begin{tabular}{|c|c|c|}
\hline \multirow{2}{*}{ Ingredients } & Experiment $1 \mathrm{~A}$ & Experiment 1B \\
\hline & $\mathrm{g} / \mathbf{k g}$ & $\mathbf{g} / \mathbf{k g}$ \\
\hline Sorghum & 450 & 450 \\
\hline Soyabean48 & 441 & 441 \\
\hline L-lysine HCL & 1.81 & 1.81 \\
\hline DL-Methionine & 1.82 & 1.82 \\
\hline Vitamin-mineral premix $†$ & 1.50 & 1.50 \\
\hline Limestone & 14.4 & 13.0 \\
\hline Salt & 3.30 & 3.30 \\
\hline Monocalcium phosphate & 13.2 & 11.8 \\
\hline Sodium bicarbonate & 1.07 & 1.07 \\
\hline Oil-sunflower & 72.3 & 69.6 \\
\hline Celite & - & 5 \\
\hline \multicolumn{3}{|l|}{ Calculated analysis } \\
\hline AME ,MJ/kg & 12.9 & 12.9 \\
\hline Crude protein & 257 & 257 \\
\hline Lysine & 15.2 & 15.2 \\
\hline Met + Cyst & 9.04 & 9.04 \\
\hline Threonine & 9.55 & 9.55 \\
\hline Tryptophan & 3.18 & 3.18 \\
\hline Calcium & 9.00 & 9.00 \\
\hline Total phosphorus & 4.00 & 4.00 \\
\hline
\end{tabular}

Table 1 Composition and calculated analysis of the starter diet 


\section{Results and discussion}

The influence of xylanase on sorghum-based broiler diets on gross performance at $1-21$ days is presented in Table 2. The broiler chickens offered sorghum variety Pan8816 and Pan8906 had similar $(P$ $>0.05$ ) feed intake, body weight and FCR from 1 to 21 days of age. The tannin-containing sorghum variety evaluated in the current study Pan8625 resulted in poor feed intake, weight gain and FCR in the period 1-7 days. These results contradict those reported by Nyachoti et al. (1996) who found that broiler chickens on high-tannin sorghum-based diets had higher feed intake and feed efficiency. These researchers went further to suggest that the effects of tannins are related to their astringency, an effect resulting from binding of salivary proteins to cause dryness in the mouth. However, as taste acuity in the chicken is not well developed, it seems unlikely that taste plays a role in decreasing feed intake.

Table 2 Influence of xylanase inclusions in sorghum broiler-based diets on feed intake (FI, g/bird), body weight gain (gain, g/bird), and feed conversion ratio (FCR, g: g, FI: BWG)

\begin{tabular}{|c|c|c|c|c|c|c|c|c|c|c|}
\hline \multicolumn{2}{|c|}{ Treatments } & \multicolumn{3}{|c|}{$1-7$ days } & \multicolumn{3}{|c|}{$1-14$ days } & \multicolumn{3}{|c|}{$1-21$ days } \\
\hline Sorghum & Enzyme & FI & BWG & FCR & FI & BW & FCR & FI & BW & FCR \\
\hline \multirow{2}{*}{ Pan8816 } & - Xylanase & $105.01^{\mathrm{ab}}$ & $141.35^{\mathrm{ab}}$ & 0.74 & 396.21 & 376.43 & 1.05 & 764.75 & 764.35 & 1.00 \\
\hline & +Xylanase & $109.42^{\mathrm{a}}$ & $144.49^{\mathrm{a}}$ & 0.75 & 399.98 & 380.40 & 1.05 & 758.64 & 730.70 & 1.03 \\
\hline \multirow{2}{*}{ Pan8906 } & - Xylanase & $107.07^{\mathrm{a}}$ & $141.81^{\mathrm{ab}}$ & 0.75 & 418.18 & 370.03 & 1.13 & 786.84 & 733.35 & 1.07 \\
\hline & +Xylanase & $105.47^{\mathrm{ab}}$ & $138.01^{\mathrm{abc}}$ & 0.76 & 400.86 & 360.48 & 1.12 & 738.81 & 706.23 & 1.04 \\
\hline \multirow{2}{*}{ Pan8625 } & - Xylanase & $96.12^{\mathrm{b}}$ & $122.92^{C}$ & 0.78 & 374.93 & 325.65 & 1.15 & 686.09 & 665.98 & 1.03 \\
\hline & +Xylanase & $106.05^{\mathrm{ab}}$ & $127.31^{b c}$ & 0.83 & 385.19 & 328.65 & 1.17 & 725.08 & 711.38 & 1.01 \\
\hline \multirow[t]{12}{*}{ SEM } & & 3.457 & 5.424 & 0.017 & 14.864 & 17.123 & 0.037 & 52.137 & 29.745 & 0.045 \\
\hline & Main effects & & & & & & & & & \\
\hline & Sorghum var & & & & & & & & & \\
\hline & Pan8816 & $107.21^{a}$ & $142.92^{a}$ & $0.75^{\mathrm{b}}$ & $398.10^{\mathrm{ab}}$ & $378.41^{a}$ & $1.05^{b}$ & $761.70^{\mathrm{a}}$ & $747.53^{\mathrm{a}}$ & 1.01 \\
\hline & Pan8906 & $106.27^{\mathrm{ab}}$ & $139.9^{\mathrm{a}}$ & $0.76^{\mathrm{b}}$ & $409.52^{\mathrm{a}}$ & $365.25^{\mathrm{a}}$ & $1.12^{\mathrm{ab}}$ & $762.82^{\mathrm{a}}$ & $719.79^{\mathrm{ab}}$ & 1.05 \\
\hline & Pan8625 & $101.08^{\mathrm{b}}$ & $125.11^{b}$ & $0.81^{a}$ & $380.06^{\mathrm{b}}$ & $327.09^{b}$ & $1.16^{\mathrm{a}}$ & $705.58^{b}$ & $688.68^{\mathrm{b}}$ & 1.03 \\
\hline & Enzyme & & & & & & & & & \\
\hline & - Xylanase & 102.73 & 135.36 & 0.76 & 396.43 & 357.37 & 1.11 & 745.89 & 721.23 & 1.03 \\
\hline & +Xylanase & 106.98 & 136.60 & 0.78 & 395.34 & 356.47 & 1.11 & 740.84 & 716.10 & 1.03 \\
\hline & Sex & & & & & & & & & \\
\hline & Male & $108.76^{a}$ & $141.33^{\mathrm{a}}$ & 0.77 & $412.32^{\mathrm{a}}$ & $377.87^{\mathrm{a}}$ & 1.09 & $805.15^{a}$ & $755.21^{a}$ & $1.06^{\mathrm{a}}$ \\
\hline & Female & $100.95^{\mathrm{b}}$ & $130.63^{b}$ & 0.77 & $379.45^{\mathrm{b}}$ & $335.97^{b}$ & 1.13 & $681.59^{b}$ & $682.12^{\mathrm{b}}$ & $0.99^{b}$ \\
\hline \multicolumn{11}{|c|}{ Significance } \\
\hline \multicolumn{2}{|c|}{ Sorghum } & 0.055 & 0.015 & 0.026 & 0.067 & 0.009 & 0.046 & 0.283 & 0.103 & 0.510 \\
\hline \multicolumn{2}{|l|}{ Enzyme } & 0.054 & 0.772 & 0.129 & 0.908 & 0.939 & 0.880 & 0.869 & 0.806 & 0.892 \\
\hline \multirow{2}{*}{\multicolumn{2}{|c|}{$\begin{array}{l}\text { Sex } \\
\text { Sorghum } \times \text { Enzyme } \times \\
\text { Sex }\end{array}$}} & 0.002 & 0.025 & 0.842 & 0.004 & 0.003 & 0.282 & 0.002 & 0.003 & 0.045 \\
\hline & & 0.128 & 0.934 & 0.812 & 0.419 & 0.975 & 0.857 & 0.540 & 0.804 & 0.227 \\
\hline
\end{tabular}

Enzyme inclusion did not improve $(P>0.05)$ the feed intake, body weight and FCR at all ages. It was apparent that enzyme supplementation had a more pronounced effect during the early phase of the feeding trial. A study by Selle et al. (2010) reported an increase in feed intake and weight gain but depressed feed efficiency when xylanase was added to sorghum-based broiler diets. This may be due to the fact that sorghum is a 'non-viscous' grain with only $4 \%$ soluble NSP (Choct, 2006; Selle et al., 2010). Furthermore, 
the disruption of insoluble NSP in sorghum endosperm cell walls by NSP-degrading enzymes is considered to be limited, which is attributed to the extent of arabinose substitution and high levels of glucuronic acid in sorghum arabinoxylan (Taylor, 2005). Ibrahim et al. (2012) indicated that inclusion of the $\beta$-glucanase enzyme in sorghum-based diets significantly decreased total feed intake and significantly improved weight gain and the FCR of broiler chickens. No treatment interaction was observed in all production parameters throughout the experimental period. Male broiler chickens had higher weight gain (7.46\%), feed intake $(11.13 \%)$, and feed efficiency $(9.64 \%)$ than females over $1-21$ days of age. Several authors have also stated that male chickens, irrespective of the strain, are superior in live and carcass weights compared to females (Gous et al., 1999; Scheuermann et al., 2003; Abudulla et al., 2010). The differences observed between male and female chickens may be the result of sexual dimorphism, which tends to favour males over females in poultry (llori et al., 2010; Peters et al., 2010).

Similar $(P>0.05)$ carcass weights, breast, thighs and drumsticks were observed in chickens on all sorghum varieties at 21 days of age (Table 3). The addition of Xylanase into diet did not improve $(P>0.05)$ meat parts yield of broiler chickens aged 21 days. These results are in agreement with the report by Elnagar and Abdel-Wareth (2014) who indicated that there was no sorghum and enzyme interaction on carcass weights and meat cut-up parts of broiler chickens aged 21 days.

Table 3 Effect of sorghum variety and xylanase supplementation carcass weight and parts yield of chickens (21d)

\begin{tabular}{|c|c|c|c|c|c|}
\hline \multicolumn{2}{|c|}{ Treatments } & \multirow{2}{*}{ CarcassWt $^{1}$} & \multirow{2}{*}{ Breast } & \multirow{2}{*}{ Thigh } & \multirow{2}{*}{ Drumstick } \\
\hline Sorghum & Enzyme & & & & \\
\hline \multirow{2}{*}{ Pan8816 } & - Xylanase & 480.15 & 122.16 & 66.05 & 67.55 \\
\hline & +Xylanase & 504.87 & 127.94 & 72.04 & 69.11 \\
\hline \multirow{2}{*}{ Pan8906 } & - Xylanase & 513.25 & 129.56 & 69.26 & 67.29 \\
\hline & +Xylanase & 450.71 & 114.26 & 65.11 & 61.51 \\
\hline \multirow{2}{*}{ Pan8625 } & - Xylanase & 459.54 & 105.18 & 62.45 & 63.49 \\
\hline & +Xylanase & 470.71 & 127.31 & 69.78 & 65.40 \\
\hline SEM & & 8.230 & 2.966 & 1.375 & 1.216 \\
\hline \multicolumn{6}{|c|}{ Main effects } \\
\hline \multicolumn{6}{|c|}{ Sorghum variety } \\
\hline Pan8816 & & 492.51 & 125.05 & 69.05 & 68.33 \\
\hline Pan8906 & & 481.98 & 121.91 & 67.19 & 64.45 \\
\hline \multirow[t]{7}{*}{ Pan8625 } & & 464.97 & 110.47 & 66.18 & 64.40 \\
\hline & Enzyme & & & & \\
\hline & +Xylanase & 484.31 & 119.32 & 68.98 & 65.34 \\
\hline & -Xylanase & 475.35 & 118.97 & 65.92 & 66.11 \\
\hline & Sex & & & & \\
\hline & Male & 477.23 & 118.71 & 67.36 & 66.54 \\
\hline & Female & 482.41 & 119.57 & 67.53 & 64.90 \\
\hline \multicolumn{6}{|c|}{ Significance } \\
\hline Sorghum & & 0.337 & 0.114 & 0.669 & 0.334 \\
\hline Enzyme & & 0.552 & 0.950 & 0.273 & 0.755 \\
\hline Sex & & 0.731 & 0.878 & 0.951 & 0.508 \\
\hline \multicolumn{2}{|c|}{ Sorghum $\times$ Enzyme $\times$ Sex } & 0.207 & 0.605 & 0.252 & 0.247 \\
\hline
\end{tabular}

${ }^{1}$ CarcassWt : Carcass weight

a,b,c Mean values in a column not sharing the same superscript are significantly different $(P<0.05)$. SEM: Standard error of the mean 
The effect of microbial enzyme and sorghum variety on relative organ weights is presented in Table 4. The small intestine was heavier $(P<0.05)$ in broiler chickens fed a tannin-containing variety, Pan8625, the variables others did not chance. The addition of xylanase were not affected $(P>0.05)$. Sex had no effect $(P$ $>0.05)$ on relative weights of organs measured except for the bursa where females had heavier $(P<0.05)$ weights than males. No treatment interaction was observed. Similar to the results of the current study Elgnagar and Abdel-Wareth (2014) reported that enzyme supplementation had no influence on organ weights. Nyachotti et al. (1996) indicated an influence of sorghum tannin on small intestinal development, resulting in low intestinal weights at 21 days and suggested that this could be due to the coarse nature of the diet.

Table 4 Effect of sorghum variety and xylanase supplementation on broiler organ weights $(\mathrm{g} / 100 \mathrm{gBW})$ at 21 days

\begin{tabular}{|c|c|c|c|c|c|c|c|}
\hline \multicolumn{2}{|l|}{ Treatments } & \multirow{2}{*}{$P+G i z^{1}$} & \multirow{2}{*}{ Sintestine $^{2}$} & \multirow{2}{*}{ Liver } & \multirow{2}{*}{ Heart } & \multirow{2}{*}{ Spleen } & \multirow{2}{*}{ Bursa } \\
\hline Sorghum & Enzyme & & & & & & \\
\hline \multirow{2}{*}{ Pan8816 } & - Xylanase & 5.30 & 6.95 & 2.80 & 0.77 & 0.11 & 0.36 \\
\hline & +Xylanase & 4.29 & 8.55 & 2.71 & 0.70 & 0.09 & 0.32 \\
\hline \multirow{2}{*}{ Pan8906 } & - Xylanase & 5.13 & 7.34 & 2.80 & 0.64 & 0.11 & 0.33 \\
\hline & +Xylanase & 4.52 & 7.41 & 2.87 & 0.72 & 0.09 & 0.37 \\
\hline \multirow{2}{*}{ Pan8625 } & - Xylanase & 4.43 & 8.97 & 2.86 & 0.64 & 0.11 & 0.31 \\
\hline & +Xylanase & 4.45 & 8.81 & 2.90 & 0.83 & 0.09 & 0.35 \\
\hline SEM & & 0.4271 & 0.327 & 0.107 & 0.051 & 0.010 & 0.051 \\
\hline \multicolumn{8}{|l|}{ Main effects } \\
\hline \multicolumn{8}{|l|}{ Sorghum variety } \\
\hline Pan8816 & & 4.80 & $7.75^{\mathrm{b}}$ & 2.76 & 0.735 & 0.102 & 0.343 \\
\hline Pan8906 & & 4.82 & $7.35^{\mathrm{b}}$ & 2.83 & 0.686 & 0.098 & 0.351 \\
\hline \multirow[t]{7}{*}{ Pan8625 } & & 4.44 & $8.89^{\mathrm{a}}$ & 2.89 & 0.740 & 0.103 & 0.328 \\
\hline & Enzyme & & & & & & \\
\hline & +Xylanase & 4.42 & 8.26 & 2.83 & 0.75 & 0.09 & 0.35 \\
\hline & - Xylanase & 4.95 & 7.75 & 2.82 & 0.68 & 0.10 & 0.33 \\
\hline & Sex & & & & & & \\
\hline & Male & 4.78 & 8.10 & 2.90 & 0.74 & 0.09 & $0.29^{b}$ \\
\hline & Female & 4.60 & 7.90 & 2.75 & 0.69 & 0.10 & $0.39^{\mathrm{a}}$ \\
\hline \multicolumn{8}{|l|}{ Significance } \\
\hline Sorghum & & 0.610 & 0.001 & 0.495 & 0.530 & 0.885 & 0.904 \\
\hline Enzyme & & 0.150 & 0.083 & 0.889 & 0.151 & 0.146 & 0.681 \\
\hline Sex & & 0.618 & 0.472 & 0.107 & 0.234 & 0.105 & 0.034 \\
\hline Sorghum $\times$ Enzyme $\times$ Sex & & 0.765 & 0.148 & 0.659 & 0.067 & 0.343 & 0.913 \\
\hline
\end{tabular}

${ }^{1}$ Proventriculus and gizzard weight with digesta; ${ }^{2}$ Small intestines with digesta

a,b,c Mean values in a column not sharing the same superscript are significantly different $(P<0.05)$.

SEM: Standard error of the mean

The nutrient digestibility of broiler chickens offered sorghum-based diets with added xylanase is shown in Table 5 . Crude protein digestibility was no affected $(P>0.05)$ by neither variety nor xylanase addition. Similar $(P>0.05)$ crude protein digestibility were observed in all diets regardless of sorghum varieties or xylanase supplementation. It was expected that a tannin-containing variety without xylanase would be poorly digested, although it is not clear how xylanase acted in the presence of tannin in this variety to improve its digestibility. Dicko et al. (2006) summarised studies that have shown that protein, proteincarbohydrate, protein-polyphenol, and carbohydrate-polyphenol interactions are the main factors affecting 
crude protein digestibility. According to Cowieson et al. (2006), it is well documented that xylanase-based enzymes act on NSP through two main modes of action.

Table 5 Nutrient digestibility (\%) of broiler chickens offered sorghum-based diets added with microbial enzymes

\begin{tabular}{|c|c|c|c|c|c|}
\hline \multicolumn{2}{|c|}{ Treatments } & \multicolumn{4}{|c|}{ Nutrient digestibility (\%) } \\
\hline Sorghum & Enzyme & Crude protein & Fat & Starch & Phosphorus \\
\hline \multirow{2}{*}{ Pan8816 } & - Xylanase & $0.65^{\mathrm{ab}}$ & $0.84^{\mathrm{a}}$ & 0.58 & 0.43 \\
\hline & +Xylanase & $0.66^{\mathrm{a}}$ & $0.66^{\mathrm{ab}}$ & 0.60 & 0.35 \\
\hline \multirow{2}{*}{ Pan8906 } & - Xylanase & $0.68^{\mathrm{ab}}$ & $0.75^{\mathrm{a}}$ & 0.65 & 0.32 \\
\hline & + Xylanase & $0.61^{\mathrm{ab}}$ & $0.66^{b}$ & 0.73 & 0.39 \\
\hline \multirow{2}{*}{ Pan8625 } & - Xylanase & $0.60^{\mathrm{b}}$ & $0.75^{\mathrm{a}}$ & 0.66 & 0.32 \\
\hline & +Xylanase & $0.65^{\mathrm{ab}}$ & $0.77^{\mathrm{a}}$ & 0.69 & 0.33 \\
\hline SEM & & 0.013 & 0.007 & 0.011 & 0.006 \\
\hline \multicolumn{6}{|l|}{ Main effects } \\
\hline Pan8816 & & 0.66 & 0.75 & 0.54 & 0.39 \\
\hline Pan8906 & & 0.64 & 0.65 & 0.69 & 0.35 \\
\hline \multirow[t]{4}{*}{ Pan8625 } & & 0.69 & 0.76 & 0.67 & 0.32 \\
\hline & Enzyme & & & & \\
\hline & - Xylanase & 0.61 & 0.78 & 0.64 & 0.35 \\
\hline & +Xylanase & 0.62 & 0.67 & 0.63 & 0.36 \\
\hline \multicolumn{6}{|l|}{ Significance } \\
\hline Sorghum & & $<.0001$ & $<.0001$ & 1.910 & 0.160 \\
\hline Enzyme & & $<.0001$ & $<.0001$ & 0.000 & 0.980 \\
\hline Sorghum $\times$ Enzyme & & 0.0001 & $<.0001$ & 0.850 & 0.138 \\
\hline
\end{tabular}

${ }_{\mathrm{a}, \mathrm{b}, \mathrm{c}}$ Mean values in a column not sharing the same superscript are significantly different $(P<0.05)$.

SEM: Standard error of the mean

Enzyme inclusion significantly increased $(P<0.05)$ the crude protein digestibility. A treatment interaction was observed $(P<0.0001)$ because numerically crude protein digestibility tended to increase when xylanase was added. Sorghum variety Pan8906 with xylanase supplementation had lower fat digestibility $(P>0.05)$ than the same variety without enzyme inclusion. Sorghum varieties with xylanase had lower $(P>0.05)$ fat digestibilities compared to those without xylanase supplementation. Sorghum Pan8816 and Pan8625 offered to broiler chickens significantly improved $(P<0.05)$ fat digestibility $(75.93$ and $76.60 \%$, respectively) compared to when Pan8906 (65.94\%) was offered to broiler chickens. Xylanase inclusions significantly yielded low $(P>0.05)$ fat digestibility.

It is uncertain why xylanase did not improve fat digestibility in the current study. Significant $(P<0.05)$ interactions between the treatments were observed. Xylanase supplemented to Pan8906 showed better $(P<0.05)$ starch digestibility than Pan8816 without xylanase additions. However, when xylanase was included in all sorghum varieties, numerically, starch digestibility tended to improve. There was no significant $(P>0.05)$ treatment interaction observed. Similar phosphorus $(P>0.05)$ digestibility values in all three sorghum varieties with or without xylanase supplementations were observed. Taylor (2005) went further to say that when the protein matrix and bodies are poorly digested, starch digestibility could be affected and digestibility of the two nutrients appear to be highly correlated. The current study is similar to that of PerezMaldonado and Rodrigues (2009) in that different sorghum cultivars were used, and starch and protein digestibility were found to be highly correlated.

\section{Conclusion}

Sorghum variety affected the growth performance of broiler chickens. Moreover, nutrient digestibility was affected by the differences in variety. However, there were some observed treatment effects in the early life of broilers chickens offered sorghum-based diets. Xylanase supplementation did not improve the 
performance and nutrient digestibility of broiler chickens. In the current study, the sorghum was fed as mash and, therefore, there might be a need to investigate and explore nutritive value of sorghum fed in different forms.

\section{Acknowledgments}

The authors would like to acknowledge and appreciate the funding from National Research Foundation (NRFGUN no: 97095), South Africa and AB Vista Marlborough, UK, for making this work possible.

\section{Authors' Contributions}

MM designed the study, executed the project and analysed data. RMG assisted in the design of the study and data analysis. MS helped with execution of the project and HVMO designed the research idea whereas PAI designed the research idea and edited the draft version of the manuscript.

\section{Conflict of Interest Declaration}

There authors declare that there is no conflict of interest.

\section{References}

Abdullah, A.Y., Al-Beitawi, N.A., Rjoup, M.M.S., Qudsieh, R.I. \& Ishmais, M.A.A., 2010. Growth performance, carcass and meat quality characteristics of different commercial crosses of broiler strains of chicken. Jpn. Poult. Sci. 47,13-21.

AOAC. 2005. Official Methods of Analysis, $18^{\text {th }}$ edition. AOAC, Washington DC, USA.

Aviagen Inc., 2014. Ross x ross 308 North American broiler performance objectives. Huntsville, AL Aviagen Inc.

Bedford, M. R. \& H. Schulz., 1998. Exogenous enzymes for pigs and poultry. Nutr. Res. Rev. 11, 91-114.

Black, J.L., Hughes, R.J., Nielsen, S.G., Tredrea, A.M., MacAlpine, R. \& Van Barneveld, R.J., 2005.The energy value of cereal grains, particularly wheat and sorghum, for poultry Proceedings of the APSS 17, 21-29.

Bryden, W.L., Selle, P.H., Cadogen, D.J., Li, X., Muller, N.D., Jordan, D.R., Gidley, M.J. \& Hamilton, W.D., 2009. A review of the nutritive value of sorghum for broilers. Publication number 09/077. Rural Industries Research and Development Cooperation (RIRDC) Canberra, Australia.

Choct, M., 2006. Enzymes for the feed industry: Past, present and future. Worlds Poult. Sci. J. 62, 5-15.

Cowieson, A.J., Acamovic, T. \& Bedford, M.R., 2006. Supplementation of corn-soy-based diets with an Escherichia coliderived phytase: Effects on broiler chick performance and the digestibility of amino acids and metabolisability of minerals and energy. Poult. Sci. 85,1389-1397.

Dicko, M.H., Gruppen, H., Zouzouho, O.C., Traoré, A.S., van Berkel, W.J.H. \& Voragen, A.G.J., 2006. Effects of germination on the activities of amylases and phenolic enzymes in sorghum varieties grouped according to food end-use properties. J. Sci. Food Agr. 86, 953-963.

Elnagar, S.H.M. \& Abdel-Wareth, A.A.A., 2014. Performance, Carcass Criteria and Profitability of Broiler Chicks as Affected by Yellow Corn Replacement with Sorghum Grains and Enzymes Supplementation. Asian J. Poult. Sci.8, 123-130.

Elnagar, S.H.M. \& Abdel-Wareth, A.A.A., 2014. Performance, Carcass Criteria and Profitability of Broiler Chicks as Affected by Yellow Corn Replacement with Sorghum Grains and Enzymes Supplementation. Asian J. Poult. 8, 123-130.

Gous R.M., Moran E.T., Stilborn H.R., Bradford G.D. \& Emmans G., 1999. Evaluation of the parameters needed to describe the overall growth, the chemical growth, and the growth of feathers and breast muscles of broilers. Poult. Sci. $78,812-821$.

Ibrahim, B., Abass, K. \& Mudawi, K., 2012. The effect of $\beta$-glucanase inclusion in sorghum based diet on performance of broiler chicks. Proceedings of the Conference on International Research on Food Security, Natural Resource Management and Rural Development, September 19-21, 2012, Georg-August Universitat Gottingen and University of Kassel-Witzenhausen, Gottingen, Germany, pp: 1-4.

Ilori, B.M, Peters, S.O., Ikeobi, C.O.N., Bamgbose, A.M., Isidahomen, C.E. \& Ozoje, M.O., 2010. Comparative assessment of growth in pure and crossbred turkeys in a humid tropical environment. Int. J. Poult. Sci. 9, 368375.

Kaufman, R. C., Herald, T. J., Bean, S. R., Wilson, J. D. \& Tuinstra, M. R., 2013. Variability in tannin content, chemistry and activity in a diverse group of tannin containing sorghum cultivars. J. Sci. Food Agr. 93,1233-1241.

Mabelebele, M., Siwela, M., Gous, R.M \& Iji, P.A., 2015. Chemical composition and Nutritive Value of South African Sorghum Varieties as Feed for Broiler Chickens. S. Afr. J. Anim. Sci. 45, 206-2013.

Nyachoti, C. M., Atkinson, J. L. \& Lesson, S., 1996. Response of broiler chicks fed a high tannin sorghum diets. J. Appl. Poult. Res. 5, 239-245.

Perez-Maldonado, R.A. \& Rodrigues, H.D., 2009. Nutritional characteristics of sorghums from Queensland and New South Wales for chicken meat production [RIRDC Publication, 07] Barton: RIRDC.

Peters, S.O., Idowu, O.M.O., Agaviezor, B.O., Egbede, R.O. \& Fafiolu, A.O., 2010. Genotype and sex effect on gastrointestinal nutrient content, microflora and carcass traits in Nigerian native chickens. Int. J. Poult. Sci 9, 731737.

Ravindran, V., Bryden, W.L. \& Kornegay, E.T., 1995. Phytates: occurrence, bioavailability and implications in poultry nutrition. Avian Poult. Biol. Rev. 16, 125-143.

SAS., 2008. Statistical Analysis Systems User's Guide: version 9.2. $2^{\text {nd }}$ Edn. SAS Institute Inc., North Caroline, USA 
Scheuermann, G.N, Bilgili, S.F, Hess, J.B. \& Mulvaney, D.R., 2003. Breast muscle development in commercial broiler chickens. Poult. Sci. 29, 332-335.

Selle, P.H., Gill, R.J. \& Downing, J.A., 2010. The vulnerability of sorghum to 'moist-heat'. Proceedings APSS. 21: 68-71.

Taylor, J.R.N., 2005. Non-starch polysaccharides, proteins and starch: form function and feed - highlight on sorghum. Proceedings of the APSS 17, 10-16.

World Sorghum Production Report, 2017. https://www.worldsorghumproduction.com/ 